\title{
Sustainable Development of Port Cities from the Perspective of Transition Management
}

\author{
Alen Jugovića, Miljen Sirotića, Ivan Peronja ${ }^{b}$
}

The strong and close relationship between the port and the city, which is often a consequence of historical circumstances, has become disrupted due to the negative impact of the port on the urban environment. The disruption of this relationship is forcing port city authorities worldwide to find effective methods to renew the port - city relationship. As an additional element to this complex relationship, the concept of sustainability is taken into consideration. Therefore, the relationship between the port and the city needs to be studied in compliance with economic, social and environmental criteria. This paper studies port and urban systems interdependently, as well as their integration into a sustainable whole. The dynamics of change in the port - city interface zone require careful planning and assessment before intervention and development. Accordingly, transition management is presented as a mechanism for renewing, coupling, and monitoring the relationship between the port and the city concerning their complex and dynamic

\author{
KEY WORDS \\ $\sim$ Port city \\ $\sim$ Sustainable development \\ $\sim$ Transition management \\ a. University of Rijeka, Faculty of Maritime Studies, Croatia \\ e-mail: ajugovic@pfri.hr \\ b. University of Split, Faculty of Maritime Studies, Croatia \\ e-mail: iperonja@pfst.hr
}

doi: 10.7225/toms.v10.n02.w01

This work is licensed under (cc) BY

Received on: 13.04.2021 / Revised on: 03.05.2021 / Accepted on: 08.06.2021 / Published online: 14.06.2021 nature. The paper's key findings are based on the contribution of relevant economic, social, and environmental criteria through which the possibility of developing a systematic framework for a coordinated transition to a cooperative relationship between the port and the city from the perspective of sustainability is realized.

\section{INTRODUCTION}

Ports and cities are historically strongly connected and are developing in close relations. The relationship between ports and cities is strengthened in such a way that increased port activity leads to increased urban activity and vice versa (Hall and Jacobs, 2012). However, in recent decades the link between ports and cities has weakened. This weakening is a consequence of the growth and development of the port and its transshipment facilities with the aim of adapting to the constantly growing, changing and dynamic market conditions. Due to continuous market competition, a negative change of social priorities regarding the use of urban space along the coast of port cities is manifested through the weakening of interest in increasing the quality of urban life. This has caused the ports to be socioeconomic drivers for a wider area (hinterland), while at the same time they are the cause of socio-economic deterioration in the neighboring areas (city and region). This duality implies that ports can have negative, but also positive external consequences that affect the well-being of the cities to which they are connected, i.e. where negative external consequences can be linked to the expansion of port territories, and positive external consequences can arise, for example, from converting obsolete ports' facilities into recreational and additional urban facilities (Saz-Salazar et al., 2015).

Ports and cities have also become places of separation of economic, environmental, and social factors. Economic and 
ecological separations are the result of the negative impact that the port has on the environment due to high levels of energy consumption, air pollution, water pollution and consumption of natural resources. Socio-technical segregations are the result of efforts aiming at achieving economic growth and development while preserving certain cultural sites, landscape, i.e. the city (Girard, 2013).

In addition, the relationship between the port and the city is characterized by a dynamic, multi-level and interconnected landscape, which has been created by a constant interaction of maritime (port) activities and associated activities of the city through trade and movement of people through migration and diaspora (Ravetz, 2013). Due to the fact that this relationship has been violated, new approaches and tools are required in order to plan and manage these separations through complementarity and the so-called "win-win" perspective, i.e. synergistic perspective (Ravetz, 2013). The authors consider it necessary to develop criteria for designing a systemic framework through which the port-city relationship could become collaborative rather than competitive. This systemic framework should be based on economic, social, and environmental criteria. The port and the city should be considered as one holistic entity and they should interact through synergy, involving all participants (port, city and intermediary) with the aim of achieving sustainability, long-term prosperity and security. This can be done through transitional management as this is perhaps the only adequate form of management for a dynamic environment such as a port city.

\section{ANALYSIS OF CHANGING DYNAMICS OF PORT - CITY RELATIONS}

The strong and close connection and mutual intertwining of the joint development of the port and the city has been a recurring topic throughout history, starting with the emergence of the earliest organized societies (civilizations). The port city or city port is a crucial element in the global maritime transport and trading system and the main drive of economic life of the majority of coastal countries. Ports are considered to be the center of local, regional, and often national and international activities (Hoyle, 2001). At the same time, port cities are key socio-economicgeographical cores because they are the leading agglomerations in terms of economic strength and influence. This statement is confirmed by the data shown in Chart 1, which shows that 14 of 20 economically strongest cities in the world are port cities (based on nominal GDP, GDP per capita, and GDP growth rate).

If factors such as the economic strength of a city, physical capital, financial maturity, and institutional effectiveness are taken

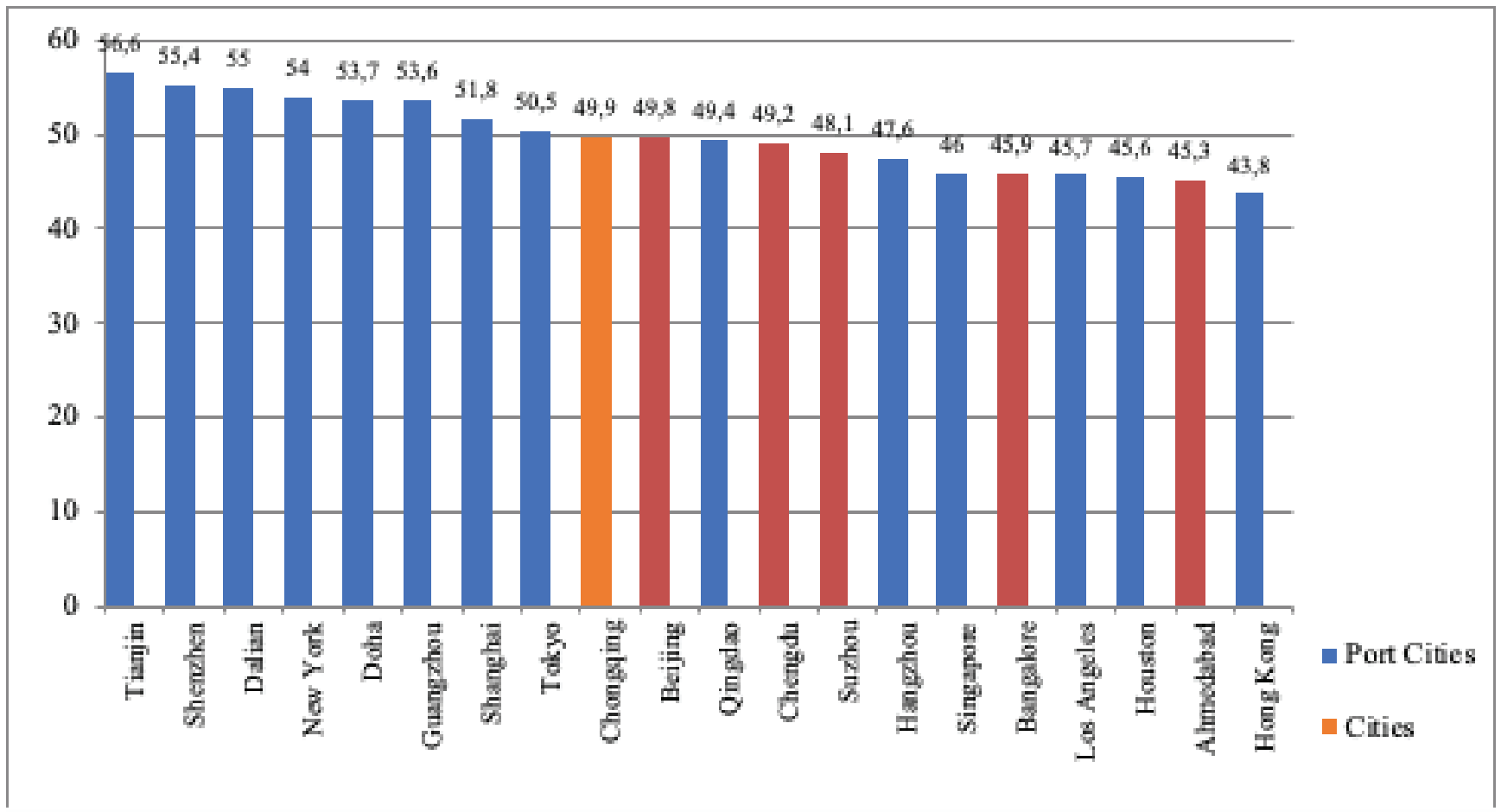

Figure 1.

Top 20 economically strongest cities in the world - Source: The Economist Intelligence Unit (2012). 
into account, port cities are the dominant core of competition; port cities account for 38 of the 50 most competitive cities in the world (Girard, 2013). Their dominant share can also be seen in the ranking of human capital indicators, among which the most prominent indicators are: population growth, share of workingage population, intensity and maturity of entrepreneurship, quality of education, and quality of health system. Taking all these criteria into account, it can be seen that 14 out of top 20 cities in the world are port cities (Girard, 2013). However, as the world started becoming more interconnected (globalization), ports within port cities gradually became exclusively specialized for maritime transport purposes, resulting in a functional breakdown of relations between ports and cities to which they originally belonged (Li, 2019).

Containerization is considered to be the main cause responsible for this administrative and spatial diffusion between ports and cities. It has spurred a rapid advancement of shipping technology, a growing demand for large areas of land required by modern port terminals in order to have as much cargo flow as possible so as to achieve the necessary agility to meet financial thresholds, and the need for a better access to inland transport networks so as to be able to achieve a better connection between the port and the hinterland (Pigna, 2014). The constant advancement of shipping technology manifested by increased dimensions of ships with the aim of achieving economies of scale has resulted in a more intense demand for greater pier depth and some additional land near the pier. The majority of city ports have reached or will reach their maximum threshold in terms of space constraints because cities are also constantly expanding and occupying limited space. Therefore, the conclusion is that the lack of cooperation between city and port is manifested in their mutual element of demand - land (as shown in Figure 1).

\section{The Evolution of a Port}

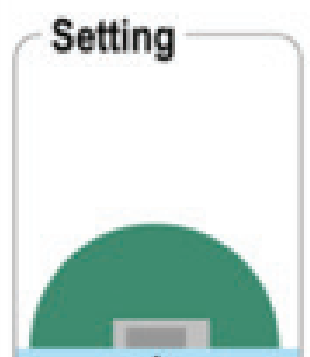

1

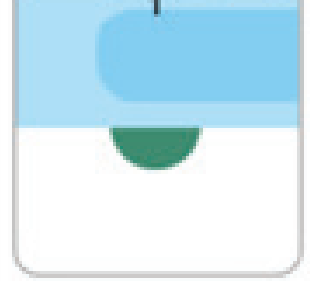

Downtown

Urban expansion

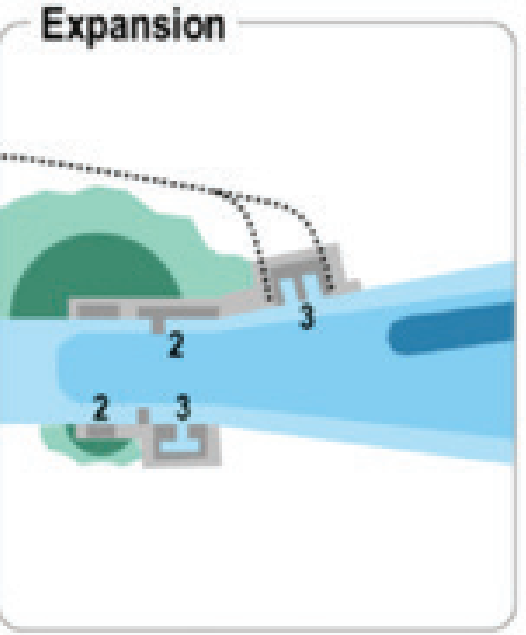

Terminal facilities

Port-related activities

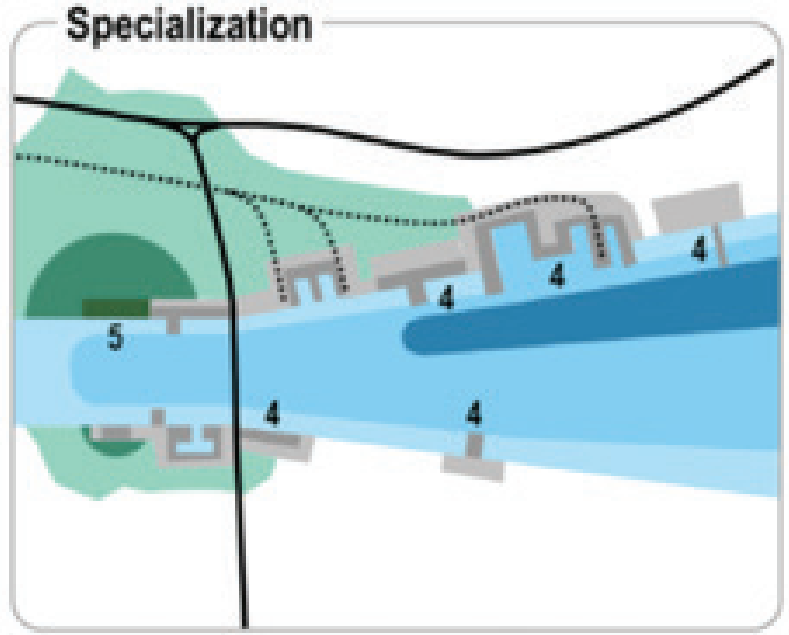

Water depth $\quad$.... Rail
$\quad$ Highway
Reconversion

Figure 2.

Overview of urban and port expansion in relation to limited free area - land - Source: Port Economics, Management, and Policy: A Comprehensive Analysis of the Port Industry.

The lack of land has encouraged ports to develop spatially as far as possible from the city center towards the sea. Such an example is the case of the Port of Rotterdam, which originated upstream, but began to expand downstream in its various developmental stages over time, with each additional expansion of the port (Merk, 2018). However, gradual expansion (relocation) of the port is possible only if there is enough free land next to the current port for further development of the port territory; this being a natural development process for ports that have sprung up in cities founded at river mouths. This is crucial only 
for ports that develop along a river mouth. Contrary to the above mentioned, many ports are located in bays and are completely surrounded by the city. In this case, the only area where the development and upgrade of the new port territory can take place is in the sea, creating an "off-shore" terminal by building embankments. It should be noted that the relocation of the port in terms of upgrading the port territory, regardless of its spatial and geographical layout, also has a negative impact on the relationship between the port and the city. This is manifested by the fact that the relocation of port operations downstream or "off-shore" leaves behind large parts of abandoned, empty and neglected heavy industrial urban land (Pigna, 2014).

This neglect of heavy industrial urban areas is also a consequence of the relocation of port transshipment machinery to port terminals, where the intensity of cargo flow is more evident. Moreover, the continuous increase in the quality of port transshipment machinery through automation, digitization, and cybernetics has resulted in a reduction in the total number of workers in ports and will continue to affect the number and structure of workers in port terminals and facilities.
Consequently, ports have ceased to be the main centers of direct employment for local urban population and have become highly developed logistics hubs within transport networks, where the direct number of employed citizens no longer has the same impact on the city (sense of community) as it once did. The manifestation of this phenomenon can be explained through the economic perspective of reducing the importance of ports in the city labor market due to increased port automation and operational rationalization, and the fact that cities have become less dependent on ports for their own local economic growth (Jacobs et al., 2010).

Taking into consideration the above mentioned, it can be concluded that the relationship between ports and cities is constantly transformed over time and that this transformation is a geographical transformation of the relationship. In academic literature this relationship is also referred to as "port - city interface" and the most relevant evolutionary model of this relationship is developed by Hoyle (1989). Hoyle's model is based on six different stages of port - city interactions, as shown in Figure 3.

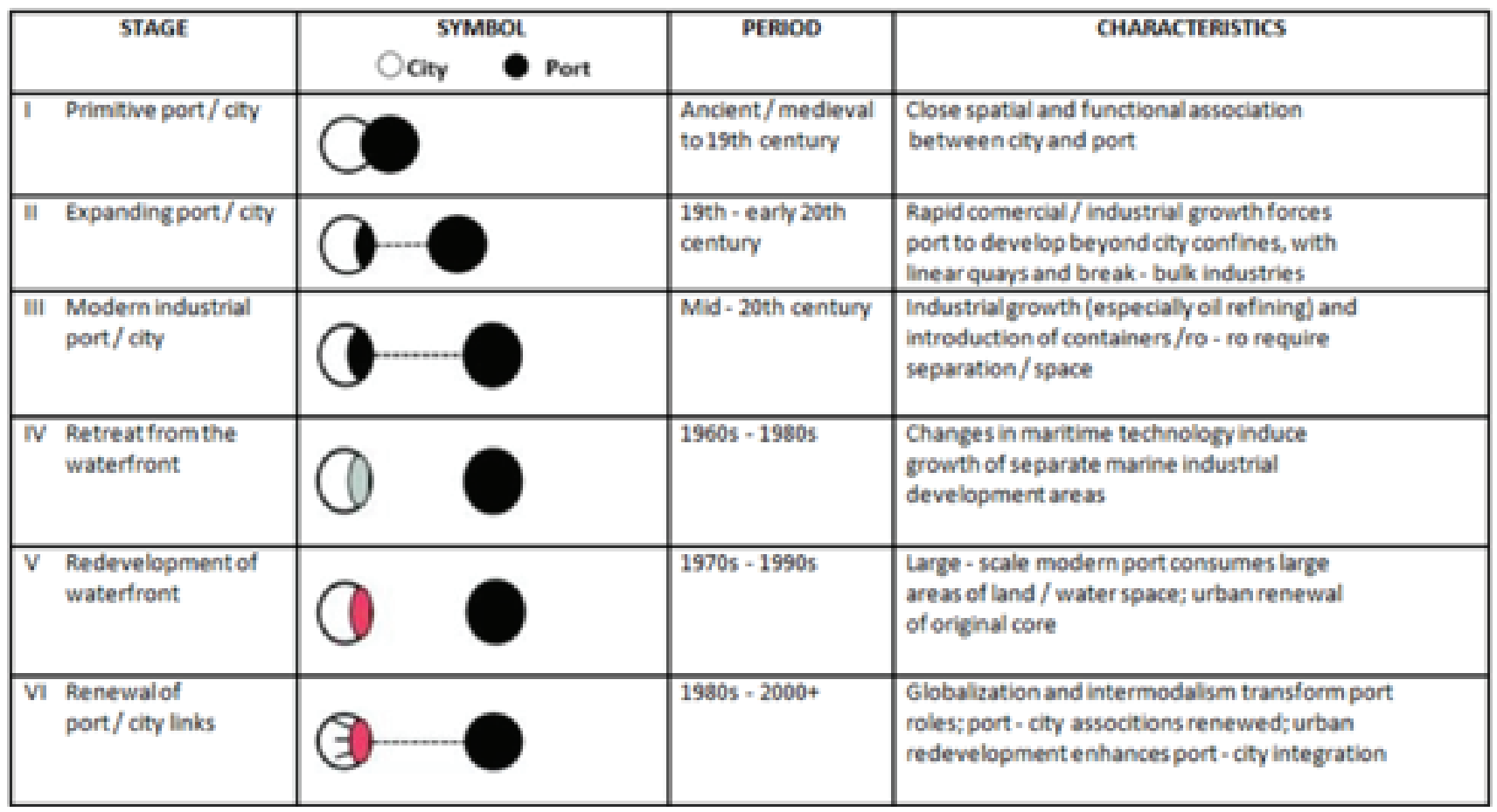

Figure 3.

Development stages of spatial evolution of the "port-city interface" relationship - Source: Hoyle (1989). 


\section{COMPLEXITY OF PORT CITY EVOLUTION THROUGH SUSTAINABLE DEVELOPMENT}

Restoring the relationship between the port and the city can be considered almost an imperative because port cities, according to their own essential characteristics, have a close relationship with the natural environment. This is reflected in the fact that private shipping companies and port authorities together oppose the laws of natural (shifting of water lines, sea level rise, threat of flooding, dredging the bottom due to deposition of sediments, climate change, etc.), which can have a significant impact on smooth functioning of maritime transport operations. Taking into account their dependence on the natural environment and their impact on the maritime industry (which is a major economic drive in most cities and countries), port cities are constantly exploring long-term economic development, creation of city wealth and resource management for the benefit of city authorities, with the aim of creating city sustainability and resilience (Hein, 2014).

Ports and cities are two different spatial economies and are always in a dynamic state of interaction and interdependence. Sustainable development is reflected in sustainable port cities through port - city interaction because the port benefits the city through its role in facilitating trade, employment, economic development, and environmental sustainability while relying on the city for the workforce and managerial talent (Zheng et al.). Finding and developing unified guidelines for the realization of a sustainable port city concept is challenging due to the fact that connecting port cities through various commodity flows creates specific spatial elements within their urban environments, including financing, technology, lifestyle, everyday life concept and building materials. The individuality of port cities is manifested in the fact that there is no specific shape, pattern, or dynamics that characterizes port cities, but still port cities show common features, which allows the study of their different characteristics through similar systematic frameworks (Hein, 2013).

Despite their individuality, port cities can be classified by influence within transport networks based on the criteria of city size (land area and population) and port activity (intensity of commodity flows manipulated within the port territory). Using these criteria, a matrix of the relationship between the port and the city is created (in terms of the degree of correlation between the port and the city) (Ducruet, 2007; Ducruet and Jeong, 2005). The matrix consists of a total of nine classification groups in terms of port - city relations. Within the matrix, the degree of correlation between the port and the city is studied in more detail through the centrality parameter, which is an urban functional parameter, and also through the intermediate parameter, which is a port functional parameter (Ducruet and Lee, 2006). The matrix contains two diametrically opposed diagonals. The first diagonal shows the optimal balanced development of the port - city relationship from the coastal city to the port metropolis, while the second diagonal shows the extremely unbalanced development within which there are two extremes, where the first is a metropolis with an insignificantly small port and the second is a world port with an insignificantly small city. In the center of the matrix, at the intersection of the diagonals, there is the port city, which can be considered an adequate balance between the port and the city. The matrix also contains the relations of the port and the city of milder balance, starting with "Out port", which depends on neighboring cities to be economically viable, and followed by "Urban port", which limits (by subordinating) its port activities to the needs of the city; "Maritime city", which by chance (without a directed intent) has efficient port and maritime activities; and "Gateway", which is characterized by the city's strong subordination to the port hinterland. The matrix of the relationship between the port and the city with the above mentioned nine classification groups regarding port - city relationships is illustrated in Figure 4.

As a concept, the port - city interface is more than six decades old; it was conceived during the 1960s to better understand the relationship between the port and the city through contemporary transformations of the urban waterfront interface. The complexity of the relationship between the port and the city seeks to be presented, analyzed, and explained in a simplified way by creating diagrams and models that depict and interpret the evolutionary trends of ports in relation to cities. Shortcomings in the analysis of the complex relationship between the port and the city are manifested in the presentation of changes in the spatial and functional relationship between the port and the city without considering the key causes of this change: economic, social, and environmental. The port city interface is a dynamic spatial concept characterized by constant change through the continuous intertwining of economic, social, and environmental factors. Due to local and global pressures today, these factors are becoming more common and current, and their amalgamation is sustainability. Therefore, it can be concluded that there is a gap in the study of the dynamic relationship between the port and city interface from the aspect of sustainability and that the "Port - City Interface" is perceived as a sensitive zone due to competition and conflict of port and city interests.

Based on the above mentioned, it is evident that research on only one element of the port - city relationship has been conducted - the geographical element. This is due to the fact 


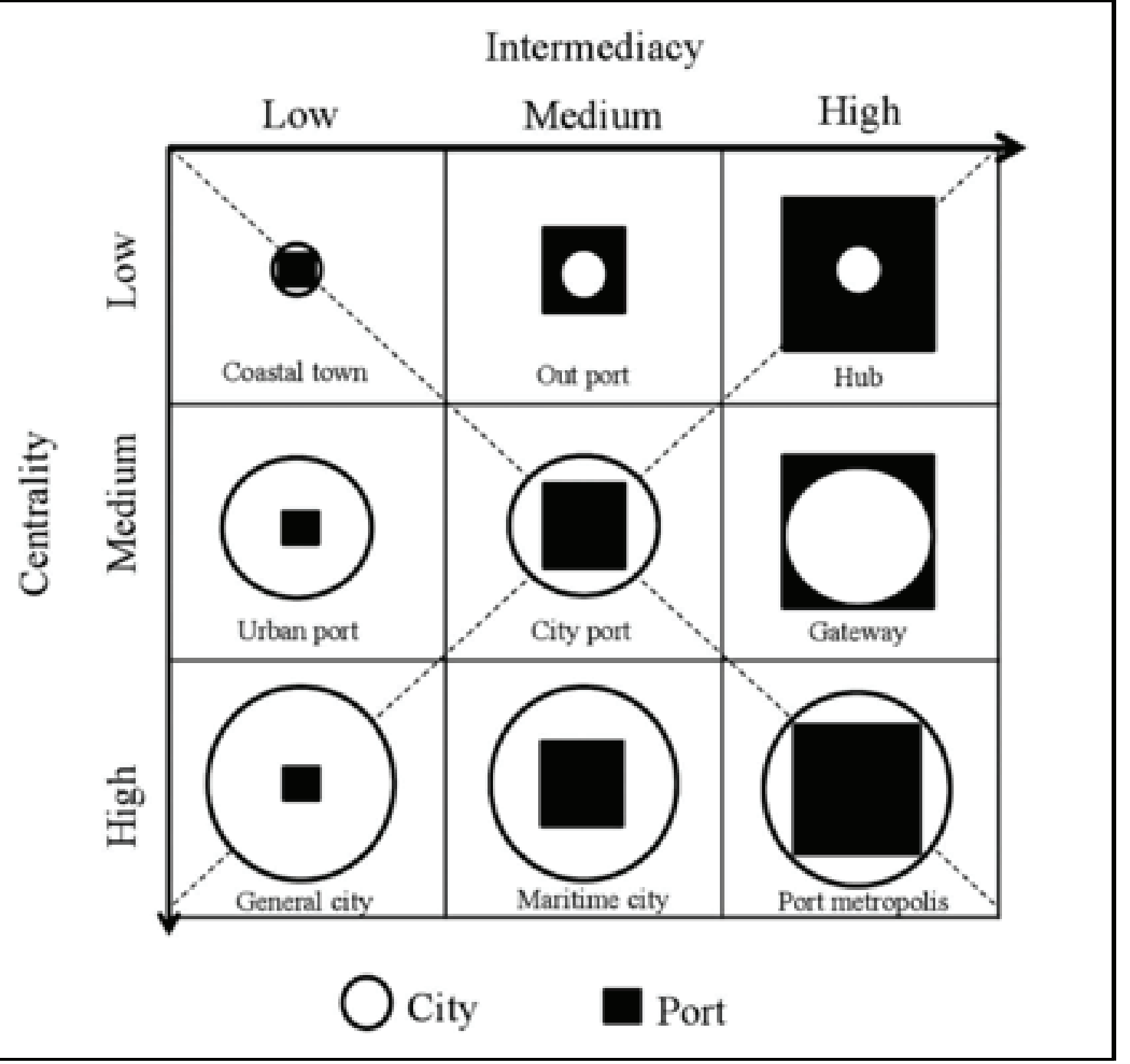

Figure 4.

Matrix of the relationship between the port and the city - Source: Ducruet and Jeong (2005).

that this element is an area of transition between the use of land by the port and the use of land by the city. The study and definition of the complex relationship between the port and the city interface exclusively from the perspective of compatible use of the available land is not based on the concept of sustainable development. This results in the fact that the complex relationship between the port and the city interface is not perceived as an interactive socio-economic- ecological system (Van der Berghe et al., 2018). Within the port and city interface, however, there are specialized business activities that are related to the port, shipping, and the city through various types of transactions (e.g. finance, risk management, consulting, etc.) (Zhao et al., 2017). These specialized business activities within the port-city interface go beyond the administrative boundaries of trade liberalization and take place irrespective of the quality of rational land use and even affect its use. In this context, the port-city interface can be considered an agglomeration of a number of port, maritime and city activities and should be perceived as a complex multidimensional dynamic entity consisting of many socio-economic-ecological layers, rather than one-dimensional through spatial analysis of the compatibility of available land for the expansion of port and urban territory (Hesse, 2017; Merk, 2014).

In this regard, it is important that the port and the city adapt to economic, social, and environmental issues and cooperate in a way that creates an integrated port city in the wider region, and 
this cooperation needs to be vital for solving problems of the past with the aim of achieving success in the future (Carpenter and Lozano, 2020). This is reflected in the fact that awareness is slowly being created about the long-term nature of port investments because focusing only on economic benefits can create accompanying environmental and social problems and, thus, ultimately compromise the tangible economic return on port investment. Therefore, the authors propose to accept the port - city interface as a dynamic and interactive socio-economic system with many participants that needs strategic coupling to enable participants to connect with territorial dynamics at local and regional level of the port city with network dynamics at national, international, and global level (Yeung, 2015).

\section{ROLE OF TRANSITION MANAGEMENT IN PORT CITY SUSTAINABLE DEVELOPMENT}

The gradual introduction of the concept of sustainability in the complex and dynamic relationship between the port and the city requires consistent consideration and the development of a planned framework for a sustainable port city development. Transitional management represents an adequate approach through which a systematic framework for planning and analyzing the current and predicting the future outcome of the development of a sustainable relationship between the port and the city could be designed. The construction of guidelines for the implementation of transitional management in port cities requires an understanding of the sustainability concept in relation to the port city. The latest definition of a sustainable port city is based on the original definition of sustainability contained in the Brundtland Report compiled in 1987 by the World Commission on Environment and Development: "The development of the port and the city should meet the current and future needs of different parties (stemming from the use of the port through market business relations) without compromising the ability of future generations to meet their own needs." (WCED, 1987; Lam and Yap, 2019). On the basis of this definition, it can be concluded that the study of the concept of sustainability in relation to the port city refers to the original elements of sustainable development that include relevant economic, social, and environmental factors.

Guiding port cities towards change in terms of the desired direction of sustainability has thus become a key challenge that needs to be accepted and institutionalized at the local, regional, and national levels. In order to properly address today's complex socio-economic-environmental problems for transition to sustainable society, it is necessary to adopt a new approach to policy and governance which is more adequate for mitigating and addressing the growing negative complexities and diversities (Loorbach, 2002). A theoretical and methodological framework that offers operational guidelines on how to establish a systemic process for strategic coupling of participants in the port-city system, taking into account interventions aimed at changes

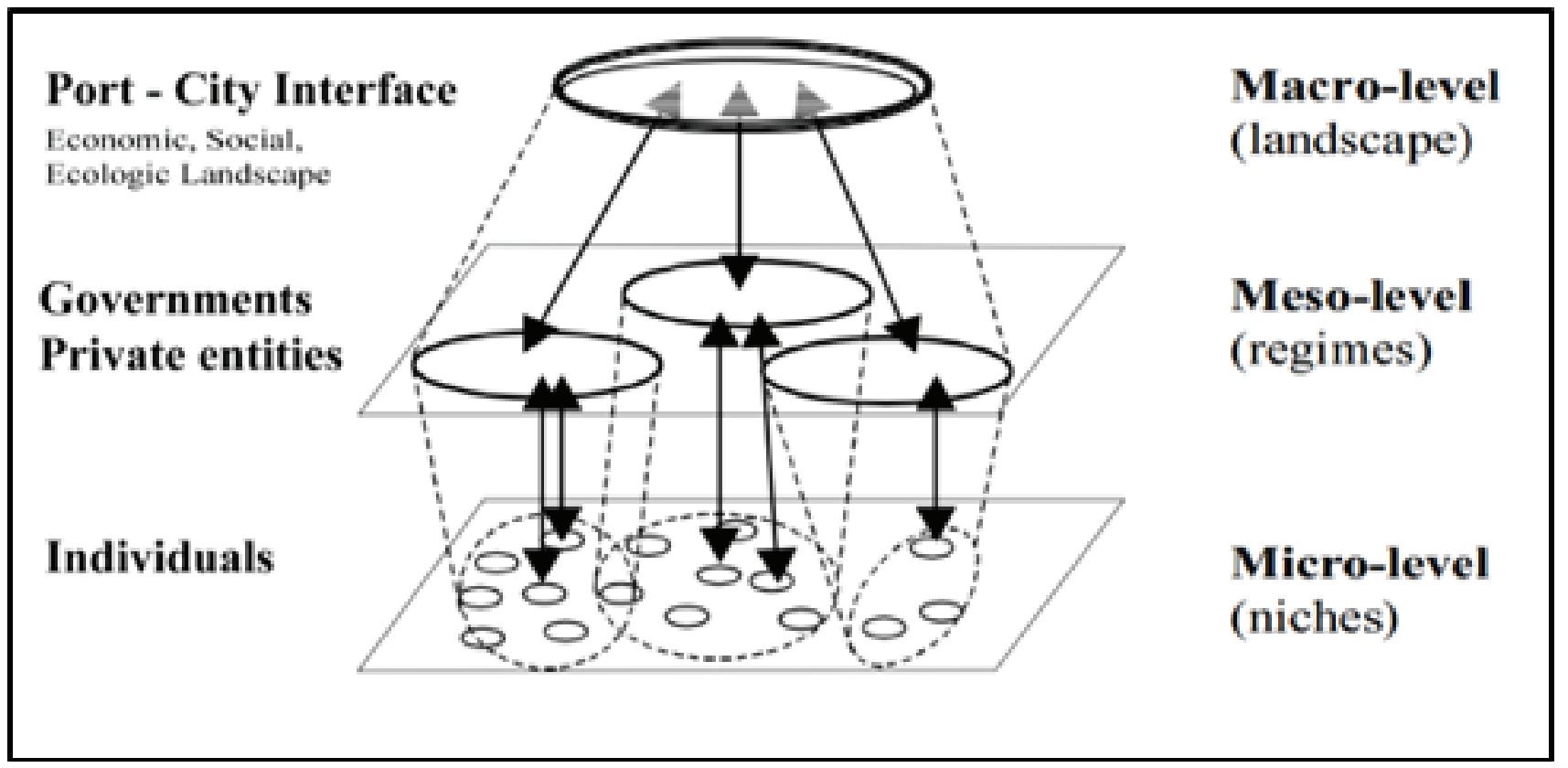

Figure 5.

Multilevel interaction of domains in transition within the port - city interface - Source: Adapted according to Geels and Schot (2007). 
in complex adaptable social (sub-)systems, is called transition management (Nevens et al., 2013).

Transition management as a form of management is based on socio-technical transformations and strategic development for socio-technical transformative changes directed towards the realization of the concept of sustainability (Jaeger, 2009). The main goal of transition management is to focus on persistent structural and cultural constraints that underlie change towards more sustainable lifestyles. This is accomplished by emphasizing the need for long-term fundamental changes in existing socio-technical systems. At the same time, through transition management, guidelines are developed and provided for understanding on how socio-technical systems such as governance, cultural systems, infrastructure, and social practices co-evolve through mutual intertwining, resulting in radical changes (Kemp et al., 2007). A precondition for the realization of the transition is to have several events in different domains (economic, social, and environmental) at different levels (micro, meso, and macro) connected and mutually reinforced. An example of multilevel domain interaction in transition within a port - city interface is shown in Figure 5.

Analysis of Figure 3 indicates that transition management is a tool through which the interplay of macro (landscape), meso (regimes) and micro (niche) levels is defined. This multilevel concept serves to provide insight into changes within a dynamic socio-economic-ecological unit such as a port city, as follows:

- Macro-level: for a port city, generic indicators such as economy, demography, political climate, and culture are taken into account because they are inert, difficult to change, but very important and influential indicators

- Meso-level: for a port city, private and public institutions and infrastructure operating within the port and city interface are taken into account, as well as their values, common opinions, customs, unwritten rules and practices. Together they form a regime that in most cases aims at protecting its own existence through maintaining the status quo, rather than changing through innovation and optimization.

- Micro-level: for a port city, individual initiatives and innovations of an individual or a group (groups) of individuals are taken into account, which analyze i.e. critically evaluate the existing regime.

These levels intertwine, and through their intertwining the transition is manifested as follows:

The meso-level (private and public institutions) is characterized by resistance to change due to the fact that they (unconsciously) respect and practice social norms, belief systems and business models that they try to perpetuate. Private and public institutions operate according to strictly defined development guidelines with an aim to better adapt to the situational circumstances on the free market. However, the resistance of the meso-level is gradually beginning to dissipate as their adaptation to market conditions is made through the emergence of socio-economic and technical innovations. Therefore, there is a manifestation of contradictions within the meso-level regime because innovations force private and public institutions to change their own strictly defined development guidelines. After a certain period of time, the mentioned contradictions, due to their size, cannot be resolved on their own and they are poured over to other levels: to the macro-level through the change of worldview and perception of the observed phenomenon, and to the micro-level through the intensification of innovation by individuals, as they begin to experiment with alternative possible solutions to difficulties and challenges within the existing levels. Thus, the transition has the following characteristics (Loorbach, 2002):

1. It is oriented towards a large-scale technological, economic, ecological, socio-cultural, and institutional development that mutually influence and strengthen each other,

2. It is a long-term, evolutionary process involving at least one generation ( 25 years),

3. There are interactions between different levels (macrolandscape, meso-regimes, micro-niches)

The study of dynamic interactions between the port and the city through transition management can be considered adequate as it proposes the development of a systemic framework aiming at sustainable development of port cities. Table 2 provides an overview of economic, environmental, and social criteria that can serve as relevant indicators for designing a systemic framework through which the concept of sustainability for the port and urban system will be accomplished in a cooperative way.

The selected relevant criteria for designing a systematic framework for the implementation of transition management, with the aim of achieving a sustainable port - city relationship are based on the fact that the port city serves as a link between the local and global economies; it is the interaction of the city and the port system and it gives importance to its complex and dynamic nature (Pitelis and Teece, 2010). Using these criteria, the city and port authorities can coordinate the transition of sustainable port - city cooperation in the following ways (Fusco Girard, 2010; Megahed, 2014; Gurpinar and Balcioglu, 2018):

1. Considering sustainability, creativity, and resilience, ports could become development opportunities for port cities.

2. Protection of the architectural cultural heritage of ports has the possibility of a positive impact on the sustainable social development of port cities.

3. Protection of the coastal ecosystem and historical heritage would have a positive impact on improving the quality of life of the local population and could promote the physical and psychological perception and health of the urban population.

4. Green operational efficiency of the port from the port waterfront and the port hinterland would promote the economic and ecological development of port cities. 
Table 1.

Relevant criteria regarding the design of a systematic framework for the implementation of transitional management with the aim of achieving a sustainable relationship between the port and the city - Source: Adapted according to PESTLE Analysis; UNCTAD (2016); Coles and Caserio (2001); Rueda (2012); ESPO Environmental Report 2019; Xiao and Siu Lee Lam (2016); Schiozzi et al. (2018).

\begin{tabular}{|c|c|c|c|}
\hline \multirow[t]{2}{*}{ General criteria } & \multirow[t]{2}{*}{ Generic criteria } & \multicolumn{2}{|c|}{ Specific criteria } \\
\hline & & Port & City \\
\hline Economic & $\begin{array}{l}\text { gross domestic product } \\
\text { interest rates } \\
\text { exchange rates } \\
\text { recessions / depressions } \\
\text { taxes } \\
\text { supply and demand ratio } \\
\text { productivity } \\
\text { added values }\end{array}$ & $\begin{array}{l}\text { port revenues } \\
\text { port costs } \\
\text { port flow } \\
\text { depreciation costs } \\
\text { port operations } \\
\text { taxes (corporate and land lease) }\end{array}$ & $\begin{array}{l}\text { GDP per capita } \\
\text { quantity of commercial activities } \\
\text { (corporate, public) } \\
\text { purchasing power of the citizen } \\
\text { productivity of the city itself } \\
\text { (labor, capital flow) }\end{array}$ \\
\hline Social & $\begin{array}{l}\text { quality of life } \\
\text { health and well-being } \\
\text { education, life skills and lifelong } \\
\text { learning } \\
\text { sense of community and local } \\
\text { identity } \\
\text { sense of security } \\
\text { social inclusion } \\
\text { recreation and sports }\end{array}$ & $\begin{array}{l}\text { safety at work } \\
\text { labor employment multiplier } \\
\text { diversity of business positions } \\
\text { sense of maritime heritage and } \\
\text { culture } \\
\text { spatial impact of port on } \\
\text { community }\end{array}$ & $\begin{array}{l}\text { unemployment rate } \\
\text { political stability } \\
\text { quality of transport, morphology } \\
\text { of the city } \\
\text { commercial social programs } \\
\text { (social inclusion) } \\
\text { transparent and efficient } \\
\text { governance }\end{array}$ \\
\hline Ecological & $\begin{array}{l}\text { waste level } \\
\text { energy consumption } \\
\text { water quality } \\
\text { water usage } \\
\text { air quality } \\
\text { soil quality } \\
\text { noise } \\
\text { carbon footprint } \\
\text { evaluation of marine ecosystems } \\
\text { assessment of terrestrial habitats }\end{array}$ & $\begin{array}{l}\text { environmental protection (air, } \\
\text { water, and soil) from pollutants } \\
\text { from ships, port transshipment } \\
\text { machinery and activities from } \\
\text { port hinterland } \\
\text { stricter conditions regarding } \\
\text { waste production (ship-recycling } \\
\text { facilities) }\end{array}$ & $\begin{array}{l}\text { environmental quality (air, water, } \\
\text { and soil) from urban activities } \\
\text { (transport) and neighboring port } \\
\text { activities } \\
\text { disposal of (hazardous) waste } \\
\text { (recycling, reuse, circularity) } \\
\text { protection of marine ecosystems } \\
\text { (coastal hydrology) }\end{array}$ \\
\hline
\end{tabular}

5. Port plans for environmental protection could guide the ecological sustainability of port cities.

The study of the development of the port-city relationship terms of sustainability from the aspect of transition management is also proposed since over several decades there has been a sharp increase in the number and scope of cooperation agreements involving ports and various participants in the vertical and horizontal value chains of ports with which they cooperate. Furthermore, after the Great Recession of 2008, special attention has been paid by the management and scientific communities to the creation, deepening, and expansion of collaborative approaches to governance (which included ports and cities). This resulted in the emergence of the concept of coopetition, which is a combination of the words cooperation and competition within the port system, the city system, and internationally distributed value chains.

Transition management provides a new, sophisticated management approach with the goal of achieving an effective port - city relationship. A new balance between the port and the city could be achieved through renewed co-orchestration and joint organization of different parties within the port and city landscape, port authorities, cargo handling companies, industrial companies, freight forwarders, distributors, shipping alliances, hinterland service providers and land terminals (Haezendonck and Verbeke, 2018). The main feature of this management model is based on the fact that port activities are becoming increasingly associated with a wider range of participants, and their operations are based on geographically dispersed economic participants, 
which are a prerequisite for long-term sustainability, growth and economic performance of ports and cities in terms of creating and capturing value (Haezendonck and Verbeke, 2018).

In this regard, it is important to achieve a new effective system of sustainable values through transition management, which will be characterized by positive economic growth with greater spill-over effects at all its levels (macro, meso, and micro). It is also necessary to focus on joint creation of opportunities and values through localized clusters and international systems. Port cities have an advantage in terms of these guidelines since they are strong economic entities supported by a long tradition of maritime activities, where different cultures and different environments meet on the border between the land and the sea (Xiao and Sie Lee Lam, 2016). Global, transport, logistics, industrial and financial hubs are extremely important as geographic entities and, therefore, play a key role in the formation of economic, social, and environmental values as people, commodities, ideas, and meanings pass through them.

\section{CONCLUSION}

Ports are considered important logistics and transport hubs with a key role in global maritime trade and movement of people. They are a place of modal exchange between maritime and land transport and have been centers of trade, investment, and innovation since the advent of civilization. Due to the already mentioned advantages that ports provide to their community, many settlements in their vicinity have developed into economically and politically influential urban agglomerations - cities. However, the cooperative relationship between the port and the city weakened in the early 1960s when the maritime transport system was radically transformed due to the implementation of containerization. This resulted in the change of both the port and the city as separate entities and at the same time it changed their relationship. Since the emergence of containerization, this newly created change in terms of separation of common interests between the port and the city is attempted to be explained using the concept of the port-city interface. By studying the concept of the port-city interface, it is concluded that the relationship between the port and the city, despite the fact that they are separated, becomes increasingly intertwined and complex as new changes affecting both the port and the city are constantly emerging.

The relations between the port and the city are thus variable, both spatially and over time, and the idea of the interdependence of port activities and urban phenomena has been re-emerging throughout the history and around the world. Today's port cities face economic, social, and environmental challenges, and their amalgamation is called sustainability. In order to achieve sustainability, ports and cities should operate in a collaborative way so that both can benefit from the mutual development (progress). The results of the research in this paper are visible in defining the guidelines for rebuilding the relationship between ports and cities through suggestion of the relevant criteria and in terms of designing a systematic framework for transitional management in a holistic way to improve the concept of sustainability between the port and the city. This framework is based on the criteria that respect the concept of sustainability by including: a) economic criteria to identify which factors affect prosperity, b) social criteria to identify which factors affect social inclusion; and c) ecological criteria to identify which factors affect the well-being of the natural environment. Using the presented theoretical concept of transition management could facilitate and improve the study of the dynamic relationship between the port and the city from all levels of the port - city interface, both today and in the future.

However, in further consideration of providing a solution for the reconciliation of the port - city relationship, a more detailed analysis of the mentioned relevant criteria is needed. In their further research, the authors are preparing to conduct an analysis of the correlation of relevant criteria through professional interviews and to test the results using the AHP method or MCDM method in order to obtain more accurate and reliable results.

CONFLICT OF INTEREST: The author(s) declares no conflict of interest.

\section{REFERENCES}

Carpenter, A. and Lozano, R., 2020. European Port Cities in Transition - Moving Towards More Sustainable Sea Transport Hubs. Springer Nature Switzerland AG, Cham, Switzerland.

Coles, R., and Caserio, M., 2001. Development of Urban Green Spaces to Improve the Quality of Life in Cities and Urban Regions. School of Architecture \& Landscape, Faculty of the Built Environment, UCE, UK, Birmingham.

Ducruet, C. \& Lee, S.-W., 2006. Frontline soldiers of globalisation: Port-city evolution and regional competition. GeoJournal, 67(2), pp.107-122. Available at: http://dx.doi.org/10.1007/s10708-006-9037-9.

Ducruet, C. and Jeong, O. J., 2005. European Port - City Interface and Its Asian Application. Gyeonggi - do: Korea Research Institute for Human Settlements.

Ducruet, C., 2007. A metageography of port - city relationships, In Wang, J., Olivier, D., Notteboom, T. \& Slack B., Ports, Cities, and Global Supply Chains, England; Ashgate Publishing Limited, Chapter 11, pp. 157 - 172.

ESPO Environmental Report, 2019. Eco Ports in Sights 2019. European Sea ports Organisation, Brussels, Belgium.

Fusco Girard, L., 2013. Toward a Smart Sustainable Development of Port Cities/ Areas: The Role of the "Historic Urban Landscape" Approach. Sustainability, 5(10), pp.4329-4348. Available at: http://dx.doi.org/10.3390/su5104329.

Geels, F.W. \& Schot, J., 2007. Typology of sociotechnical transition pathways. Research Policy, 36(3), pp.399-417. Available at: http://dx.doi.org/10.1016/j.respol.2007.01.003. 
Haezendonck, E. \& Verbeke, A., 2018. Introduction: Co-orchestrating Sustainable Port Ecosystems. Sustainable Port Clusters and Economic Development, pp.1-8. Available at:

http://dx.doi.org/10.1007/978-3-319-96658-8_1.

Hall, P.V. \& Jacobs, W., 2012. Why are maritime ports (still) urban, and why should policy-makers care? Maritime Policy \& Management, 39(2), pp.189-206. Available at: http://dx.doi.org/10.1080/03088839.2011.650721.

Hein, C., 2013. Port Cityscapes: Town and Harbour Development in the Global Context.

Hein, C., 2014. Port cities and urban wealth: between global networks and local transformations. International Journal of Global Environmental Issues, 13(2/3/4), p.339. Available at:

http://dx.doi.org/10.1504/ijgenvi.2014.064510.

Hesse, M., 2017. Approaching the Relational Nature of the Port-City Interface in Europe: Ties and Tensions Between Seaports and the Urban. Tijdschrift voor economische en sociale geografie, 109(2), pp.210-223. Available at:

http://dx.doi.org/10.1111/tesg.12282.

Hoyle, B., 2001. Fields of Tension: Development Dynamics at the Port-City Interface. Jewish Culture and History, 4(2), pp.12-30. Available at:

http://dx.doi.org/10.1080/1462169x.2001.10512227.

Hoyle, B.S., 1989. The port-City interface: Trends, problems and examples. Geoforum, 20(4), pp.429-435. Available at:

http://dx.doi.org/10.1016/0016-7185(89)90026-2.

Jacobs, W. et al., 2010. Integrating world cities into production networks: the case of port cities. Global Networks, 10(1), pp.92-113. Available at: http://dx.doi.org/10.1111/j.1471-0374.2010.00276.x.

Jäger, J., 2009. The governance of science for sustainability W. N. Adger \& A. Jordan, eds. Governing Sustainability, pp.142-158. Available at: http://dx.doi.org/10.1017/cbo9780511807756.009.

Kemp, R., Loorbach, D. \& Rotmans, J., 2007. Transition management as a model for managing processes of co-evolution towards sustainable development. International Journal of Sustainable Development \& World Ecology, 14(1), pp.78-91. Available at:

http://dx.doi.org/10.1080/13504500709469709.

Lam, J. \& Yap, W., 2019. A Stakeholder Perspective of Port City Sustainable Development. Sustainability, 11(2), p.447. Available at: http://dx.doi.org/10.3390/su11020447.

Li, Z., 2018. Conflicts and Reconciliation at the Port-City Interface in Contemporary European Cities. Engineering Management Research, 8(1), p.1. Available at: http://dx.doi.org/10.5539/emr.v8n1p1.

Loorbach, D., 2002. Transition Management: Governance for Sustainability, DRIFT Dutch Research Institute for Transitions, pp. 1 - 15.

Merk, O., 2014. The Port - city Interface: What is It, and How to Improve It?, Paper given at the 2014 Conference of AIVP in Durban, South Africa, Unpublished Manuscript.

Merk, O., 2018. Containership size and port relocation, Discussion Paper. International Transport Forum, Paris.
Nevens, F. et al., 2013. Urban Transition Labs: co-creating transformative action for sustainable cities. Journal of Cleaner Production, 50, pp.111-122. Available at: http://dx.doi.org/10.1016/j.jclepro.2012.12.001

PESTLE Analysis: Economic Factors Affecting Business. Available at: https:// pestleanalysis.com/economic-factors-affecting-business/.

Pigna, F.J., 2014. The City - Port Relationship: its evolution, changing dynamics and challenges for port authorities. Sefacil Foundation.

Pitelis, C.N. \& Teece, D.J., 2010. Cross-border market co-creation, dynamic capabilities and the entrepreneurial theory of the multinational enterprise. Industrial and Corporate Change, 19(4), pp.1247-1270. Available at: http://dx.doi.org/10.1093/icc/dtq030.

Port Economics, Management and Policy: A comprehensive analysis of the port industry. Available at: https://porteconomicsmanagement.org/.

Ravetz, J., 2013. New Futures for Older Ports: Synergistic Development in a Global Urban System. Sustainability, 5(12), pp.5100-5118. Available at: http://dx.doi.org/10.3390/su5125100.

Rueda, S., 2012. Ecological Urbanism Certification - Urbanism Certification with Sustainability Criteria. Barcelona Urban Ecology Agency, Barcelona.

Saz-Salazar, S. del, García-Menéndez, L. \& Merk, O., 2015. Port-City Relationship and the Environment: Literature Survey and Methodological Approach for Project Appraisal in Presence of Environmental Externalities. Journal of Urban Planning and Development, 141(3), p.04014029. Available at: http://dx.doi.org/10.1061/(asce)up.1943-5444.0000230.

Schiozzi, D., Jugović, A. \& Smojver, Ž., 2018. Comparative Analysis of the Related Interests of Relevant Stakeholders in the Development of Seaports in Relation to the Spatial Concept of the City. Pomorstvo, 32(1), pp.36-41. Available at: http://dx.doi.org/10.31217/p.32.1.17.

The Economist Intelligence Unit, 2012. Hot Spots Benchmarking global city competitiveness, The Economist Intelligence Unit Limited 2012, pp.1 - 39.

UNCTAD., 2016. Port Performance - Linking Performance Indicators to Strategic Objectives. United Nations, Switzerland, Geneva.

Van den Berghe, K., Jacobs, W. \& Boelens, L., 2018. The relational geometry of the port-city interface: Case studies of Amsterdam, the Netherlands, and Ghent, Belgium. Journal of Transport Geography, 70, pp.55-63. Available at: http://dx.doi.org/10.1016/j.jtrangeo.2018.05.013.

WCED, 1987. Our Common Future (First), Oxford, Oxford University Press.

Xiao, Z. and Siu Lee Lam, J., 2016. A Systems Framework for Sustainable Development of Port City: Case Study of Singapore's Policies. Research in Transportation Business and Management, 22, pp.255 - 262. Available at: https://doi.org/10.1016/j.rtbm.2016.10.003.

Yeung, H. W. C., 2015. Regional Development in the Global Economy: A Dynamic Perspective of Strategic Coupling in Global Production Networks, Regional Science Policy \& Practice 7, pp. 1 - 23.

Zhao, Q. et al., 2017. Building a bridge between port and city: Improving the urban competitiveness of port cities. Journal of Transport Geography, 59, pp.120-133. Available at:

http://dx.doi.org/10.1016/j.jtrangeo.2017.01.014. 